\title{
2. DYSPROPORCJE WARUNKÓW I JAKOŚCI ŻYCIA MIESZKAŃCÓW JEDNOSTKI OSIEDLOWEJ TEOFILÓW W ŁODZI. PRZYKŁAD OSIEDLI ROJNA I ROGATKA
}

\subsection{Wprowadzenie}

Cechą współczesnego miasta jest jego duże zróżnicowanie zarówno w sferze gospodarczej, fizjonomicznej, jak i społecznej. Przyczyn tego stanu można upatrywać w postępującej globalizacji i w uwarunkowaniach lokalnych - historycznych (geneza miasta, jego funkcja, zastane struktury społeczne i gospodarcze), specyfiki kultury mieszkańców i wynikającej z niej skłonności do podejmowania indywidualnych lub zbiorowych działań, przywiązania do miasta, wartościowania oraz poczucia odpowiedzialności za otaczającą przestrzeń (Wójcik, Tobiasz-Lis 2013).

W sferze społecznej, zróżnicowanie może dotyczyć wielu aspektów. Niewątpliwie jednym z nich są warunki i jakość życia mieszkańców, które szczególnie po roku 1989 wskutek m.in. wzrastającego drastycznie rozwarstwienia społecznego uległy znacznym przemianom i silnej dywersyfikacji. Coraz częściej we współczesnej przestrzeni miejskiej można bowiem zaobserwować z jednej strony postępujący proces degradacji starej substancji mieszkaniowej i jednocześnie rozwój indywidualnie zaprojektowanych, kameralnych osiedli wielorodzinnych, bardzo nowoczesnych w formie, najczęściej jednak zamkniętych, monitorowanych i chronionych. Tempo tego procesu jest na tyle duże, że dysproporcje w tej sferze dotyczą coraz to mniejszych przestrzeni. Można je dostrzec nie tylko między dzielnicami tego samego miasta, ale coraz częściej także w obrębie jednej dzielnicy, osiedla mieszkaniowego, a nawet pojedynczej ulicy.

Głównym celem artykułu jest przedstawienie dysproporcji warunków i jakości życia mieszkańców jednostki osiedlowej Teofilów w Łodzi na przykładzie dwóch jednostek urbanistycznych (osiedli) - Rojna i Rogatka. Artykuł zmierza zwłaszcza do analizy różnic w warunkach i jakości życia mieszkańców w wyróżnionych jednostkach urbanistycznych oraz wyjaśnienia przyczyn tego zróżnicowania. Przedmiotem analizy jest zarówno podłoże materialne osiedli Rogatka i Rojna, w tym jego komponenty przy- 
rodnicze i antropogeniczne oraz zbiorowość ludzi, którzy je zamieszkują i ich społeczna percepcja.

Zakres przestrzenny obejmuje obszar dwóch jednostek urbanistycznych - Rogatka i Rojna. Jednostki te położone są w granicach Teofilowa Mieszkaniowego (Teofilów C) rozciągającego się na południe od ulicy Aleksandrowskiej. Granice obszaru badań wyznaczają następujące ulice: Aleksandrowska (na północy), Rojna (na południu), Wici (na wschodzie) i Szczecińska (na zachodzie). Wybór przedstawionego terenu nie jest dziełem przypadku. Jest to obszar zróżnicowany pod względem fizjonomicznym. W jego granicach znajduje się zarówno zabudowa wielorodzinna reprezentowana przez typowe blokowisko (wieżowce) z tzw. wielkiej płyty wybudowane w latach 60. i 70. (Rogatka) i zabudowa jednorodzinna szeregowa, powstała w latach 80. (Rojna).

Do analizy warunków i jakości życia mieszkańców wykorzystano dane pochodzące $\mathrm{z}$ dwóch źródeł. Pierwszym z nich była inwentaryzacja terenowa wybranych osiedli, przy czym uwagę skupiono głównie na elementach czytelnych dla przeciętnego obserwatora, tj. wyglądzie i kondycji technicznej budynków oraz zagospodarowaniu osiedla (stan dróg, chodników, skwerów zieleni, utrzymanie czystości itp.). Drugi pochodził z wywiadów kwestionariuszowych i swobodnych, które przeprowadzono z ich mieszkańcami. W obu przypadkach materiał zebrano w maju i w czerwcu 2012 i 2013 r. W sumie, w badaniu udział wzięło 100 osób, po 50 z każdej jednostki osiedlowej. Należy dodać, że przeprowadzone badania z uwagi na małą liczebność grupy nie są reprezentatywne i mają jedynie charakter diagnozy. Wśród ankietowanych nieco większą grupę (54\%) stanowiły kobiety. Ankietowani to również w większości ludzie w wieku średnim (46-60 lat - 36\%), dobrze lub bardzo dobrze wykształceni (wykształcenie średnie i wyższe zadeklarowało w sumie $71 \%$ badanych), reprezentujący różne grupy zawodowe, w tym najczęściej takie jak: specjalista, rzemieślnik, technik, pośrednik handlowy, nauczyciel i przedsiębiorca. Warto podkreślić, że wśród ankietowanych dominowały zarazem osoby, które na badanym obszarze zamieszkują dłużej niż 15 lat (42\%).

Mimo że badania warunków i jakości życia są wśród zagranicznych i polskich geografów podejmowane od dawna to nie wypracowano do tej pory jednorodnej terminologii i nie skonstruowano jednoznacznych definicji. W dużej mierze wynika to $\mathrm{z}$ ogromnej złożoności tych zagadnień, a także z różnych podejść do przywołanego problemu. Nie mniejsze znaczenie ma także, podkreślona przez Liszewskiego, słabo wykształcona metodologia badań oraz trudności przy ich systematyzowaniu i rozróżnianiu aspektów określających stopień zaspokojenia potrzeb człowieka (Liszewski 1995). W literaturze przedmiotu warunki życia najczęściej jednak utożsamia się z możliwością zaspokojenia potrzeb w określonym środowi- 
sku i definiuje jako: obiektywnie istniejące możliwości zaspokajania potrzeb społecznych mieszkańców (Rembowska 1994), stan zaspokojenia wszelkich potrzeb wynikających z otoczenia (środowiska), życia i działania człowieka (Gorzelak 1985; Liszewski 2004), czy też jako całokształt czynników determinujących zaspokojenie potrzeb ludzkich, przy czym rozróżnia się warunki życia społecznego, ekologiczne warunki życia, warunki życia osobistego i warunki pracy (Hodoly 1975). Jakość życia natomiast ujmowana jest najczęściej jako stopień zadowolenia człowieka z warunków życia, czyli ze stanu w jakim żyje (Liszewski 2004), subiektywnie odczuwany poziom zaspokojenia potrzeb przez ludność (Rembowska 1994) lub też jako zbiór potrzeb, których zaspokojenie czyni ludzi szczęśliwym (Rutkowski 1989). Warto przy tym podkreślić, że w przeciwieństwie do warunków życia, które są kategorią mierzalną, jego jakość jest trudno mierzalna, gdyż określa przede wszystkim stan świadomości człowieka i opiera się na zindywidualizowanym systemie ocen. W konsekwencji, mierniki służące badaniom warunków oraz jakości życia są zróżnicowane. Do pomiaru warunków życia najczęściej wykorzystuje się takie jak: warunki zamieszkania, warunki pracy, warunki bytowe, rozwój infrastruktury społecznej i dostępność do niej mieszkańców, natomiast do pomiaru jakości życia stan zdrowia mieszkańców, stan zamożności materialnej, poczucie bezpieczeństwa, poczucie wolności osobistej, identyfikacje $\mathrm{z}$ miejscem i poczucie satysfakcji z miejsca zamieszkania (Liszewski, 2004).

W niniejszym artykule przez „warunki życia” rozumie się mierzalne, obiektywne możliwości zaspokojenia potrzeb ludzkich identyfikowane m.in. poprzez warunki mieszkaniowe (rozumiane jako suma standardu zamieszkania, budynku mieszkalnego oraz otoczenia), poziom zamożności mieszkańców, infrastrukturę techniczną i społeczną, usługi oraz ich dostępność dla mieszkańców. Jakość życia natomiast definiuje się jako społeczną percepcję poszczególnych dziedzin życia, w tym warunków życia, a także stopnia zaspokojenia potrzeb. Wśród mierników wyróżnia się m.in. poczucie bezpieczeństwa, zadowolenie z sytuacji materialnej i mieszkaniowej oraz relacji z rodziną i znajomymi.

\subsection{Charakterystyka wybranych do badań osiedli - Rojna i Rogatka}

Aktualna sytuacja w zakresie warunków i jakości życia w mieście jest wypadkową działania wielu różnych czynników. W największym stopniu wpływ mają: stan sprzed roku 1989, możliwości i efekty działań samorządu terytorialnego, atrakcyjność miast dla podmiotów gospodarczych, w tym także inwestorów krajowych i zagranicznych oraz zamożność i aktywność mieszkańców (Parysek 2004). W skali pojedynczego osiedla kluczową rolę odgrywają natomiast: jego położenie w strukturze prze- 
strzennej miasta, struktura morfologiczna, stopień zamożności mieszkańców, bezpieczeństwo, stopień wyposażenia w usługi i infrastrukturę, stan środowiska przyrodniczego, jak też standard zamieszkania i najbliższego otoczenia.

Oba wybrane do badań osiedla znajdują się w Łodzi w jednostce osiedlowej Teofilów Wielkopolski i położone są w granicach Teofilowa Mieszkaniowego. Teofilów Mieszkaniowy położony jest w północno-zachodniej części Łodzi, na peryferiach miasta. W linii prostej odległość jego zachodnich granic od centrum miasta wynosi $6 \mathrm{~km}$. Przez łodzian obszar ten postrzegany jest jednak jako miejsce „przyjazne” do życia. Za taką oceną przemawia przede wszystkim jego korzystne położenie komunikacyjne przy skrzyżowaniu ulic Aleksandrowskiej i Szczecińskiej. Ulica Aleksandrowska jest drogą wojewódzką nr 709 i jednocześnie stanowi odcinek linii krajowej nr 72. Pełni ona funkcję szlaku komunikacyjnego dla całego miasta w kierunku pólnocno-zachodniej Polski. Dla mieszkańców oznacza to możliwość łatwego dojazdu do miejscowości takich, jak Aleksandrów Łódzki, Poddębice, a dalej do Poznania czy Szczecina. Duże znaczenie ma także ulica Szczecińska zapewniająca najkrótsze połączenie za Zgierzem oraz Konstantynowem Łódzkim. Ponadto, Teofilów Mieszkaniowy ma także dobrze rozwiniętą sieć komunikacji miejskiej, głównie dzięki ulicy Aleksandrowskiej gdzie skupia się ruch tramwajowy, oraz ulicy Rojnej, gdzie spotykają się trasy aż 7 linii autobusowych. Sprawia to, że mimo peryferyjnego położenia mieszkańcy Teofilowa Mieszkaniowego nie czują się „odcięci” od reszty miasta. Warto podkreślić, że mieszkańcy osiedli Rogatka i Rojna są pod tym względem szczególnie uprzywilejowani, gdyż właśnie te obszary skupiają największą liczbę połączeń komunikacyjnych - pięć na osiedlu Rogatka i cztery na osiedlu Rojna. Na plus należy również zaliczyć duży udział terenów zielonych takich jak parki, skwery, szpalery drzew wzdłuż ulic, zieleń między blokami oraz ogródki działkowe. Nie bez znaczenia jest także fakt, że Teofilów Mieszkaniowy cechuje dość „luźna” zabudowa i duży udział terenów niezabudowanych, tj. łąk i nieużytków, terenów rolniczych, ogródków działkowych, fragmentów lasu, zlokalizowanych szczególnie w jego zachodniej i południowej części. Stąd w opinii społecznej Teofilów Mieszkaniowy funkcjonuje jako osiedle spokojne, ciche i raczej bezpieczne.

Pod względem urbanistycznym Teofilów Mieszkaniowy zaprojektowano w latach 60. i 70. XX w. Jego cechą charakterystyczną jest duże zróżnicowanie zabudowy. Wśród budynków pełniących funkcję mieszkaniową wyróżnia się bowiem domy jednorodzinne wolnostojące, domy jednorodzinne szeregowe, bloki czteropiętrowe, jak i bloki dziesięcio- i jedenastopiętrowe. Tak duże zróżnicowanie sugeruje zatem istnienie znacznych dysproporcji w warunkach i w jakości życia na tym obszarze. 


\subsection{Zróżnicowanie warunków życia w wybranych osiedlach}

Gwałtowny rozwój funkcji mieszkaniowej na badanym osiedlu nastąpił w latach 60. i 70. XX w. i był wyrazem realizacji przez państwo zadań w zakresie rynku mieszkaniowego. Oba wybrane do badań osiedla, choć różnią się formą zabudowy, reprezentują typ wielkopłytowego budownictwa prefabrykowanego (tzw. osiedla z wielkiej płyty) i zostały wzniesione przez Robotniczą Spółdzielnię Mieszkaniową „Lokator”. Pierwsze z nich wybudowano w latach 1978-1979, natomiast drugie w latach 80 . Osiedla te powstały na obszarze zajętym uprzednio przez grunty orne, a zatem na terenach odznaczających się niskim stopniem zainwestowania.

Osiedle Rogatka położone jest na południe od ulicy Aleksandrowskiej oraz na wschód od ulicy Szczecińskiej. Zaletą tej lokalizacji było sąsiedztwo terenów wolnych od zabudowy, choć dla celów rekreacyjnych nie były one zbyt atrakcyjne. Minusem, sąsiedztwo znajdujących się po przeciwległej stronie ulicy Aleksandrowskiej terenów przemysłowych. W większości tereny te nie emitowały jednak uciążliwych zanieczyszczeń czy hałasu, a od zabudowy mieszkaniowej były i są oddzielone dość szeroką strefą izolacyjną (Borowicz, Grochowski, 1977).

Na terenie osiedla Rogatka wybudowano siedem jedenastokondygnacyjnych bloków, które wyróżnia małe zróżnicowanie pod względem zarówno wyglądu, jak i jakości wykonania, gdyż cechą charakterystyczną budownictwa wielorodzinnego z okresu socjalizmu było wykorzystanie gotowych prefabrykatów betonowych, z których powstawały niemal identyczne bloki oraz podobnych technik budownictwa. Wszystkie znajdujące się tam bloki mają kształt zbliżony do prostopadłościanu z płaskim dachem. Osiedle to liczy w sumie 835 mieszkań, od jedno- do czteropokojowych i każde $\mathrm{z}$ nich wyposażone jest $\mathrm{w}$ kuchnię, łazienkę i WC. Powierzchnia mieszkań wynosi od 31 do $80 \mathrm{~m}^{2}$. Na każdym piętrze znajdują się po trzy mieszkania: M3 o powierzchni $45 \mathrm{~m}$, M4 liczące $63 \mathrm{~m}$ oraz $76 \mathrm{~m}$ M6. Z planów mieszkań wynika, że są one ustawne i dobrze rozplanowane. Należy podkreślić, że już w momencie oddania bloków do użytku mieszkania te były wyposażone także w tzw. wszelkie wygody, tj. bieżącą wodę (zimną i ciepłą), kanalizację, gaz ziemny, centralne ogrzewanie i elektryczność. W sumie osiedle Rogatka stanowiło bardzo atrakcyjne miejsce zamieszkania w przestrzeni ówczesnej Łodzi. Wpływało na to położenie na peryferiach miasta (jednak z możliwością łatwego dostania się do jego centrum), które generowało ciszę, spokój i dostęp do terenów zielonych. Warto ponadto wspomnieć, że atrakcyjna była również wysokość czynszu, nieco niższa niż w innych dzielnicach.

W przeciwieństwie do innych łódzkich osiedli na osiedlu Rogatka nie odczuwa się klaustrofobii wywołanej otoczeniem miejskich molochów. 
Sprzyja temu „luźne” rozmieszczenie budynków, ustawionych najczęściej bokiem względem siebie, co rozwiązuje również problem podglądania przez sąsiadów. Co więcej, w najbliższym otoczeniu osiedla niewiele jest innych budynków, a te obecne są niskie i towarzyszą im aleje drzew. Dużym walorem jest ponadto sąsiedztwo Parku Piastowskiego o powierzchni 4,37 ha (z parkiem sąsiaduje pięć spośród siedmiu bloków osiedla) oraz Zespół Ogródków Działkowych.

Współcześnie wizerunek osiedla uległ znacznej poprawie. W roku 2007 szare, monotonne barwy, na skutek działań spółdzielców zostały zastąpione pastelowymi kolorami, w efekcie czego budynki przestały przypominać duże kartonowe pudła.

Problemem osiedla Rogatka, szczególnie w kontekście wciąż wzrastającej liczby samochodów jest brak miejsc parkingowych. Zmotoryzowani mają niewielkie możliwości w zakresie pozyskania nowych miejsc parkingowych, osiedle bowiem nie dysponuje rezerwami wolnych terenów. Problem tylko częściowo rozwiązują znajdujące się na terenie osiedla zadaszone garaże, które mieszkańcy mogą wynająć od spółdzielni za dodatkową opłatą, ogólnodostępne parkingi przed blokiem i parkingi strzeżone. Liczba oferowanych na osiedlu miejsc parkingowych jest jednak wiąż nieadekwatna do istniejących $w$ tym zakresie potrzeb.

Poza już wymienionymi, warunki życia w dużym stopniu zależą także od wyposażenia osiedla w usługi. Pod tym względem „Rogatka” należy do najbardziej uprzywilejowanych na całym Teofilowie i to zarówno pod względem liczby punktów usługowych, jak i ich dostępności. W granicach badanego obszaru funkcjonuje ponad 15 różnego rodzaju punktów usługowych, w tym najwięcej z branży handlowej zaspokajającej podstawowe potrzeby mieszkańców, tj. sklepy spożywcze, odzieżowe. Ponadto mieszkańcy mogą także skorzystać z usług bankowych, gastronomicznych (pizzeria), kosmetycznych, krawieckich i medycznych, które oferują pomoc wielu lekarzy specjalistów. Stosunkowo najsłabiej rozwinięte są usługi kulturalne i rozrywkowe, choć w niedalekim sąsiedztwie zlokalizowany jest Dom Kultury „Relax”. Współcześnie osiedle Rogatka zamieszkuje 2,5 tys. osób ${ }^{1}$, przy czym w strukturze wiekowej dominują emeryci i renciści (23\%). Dominacja osób starszych sugeruje, że osiedle to należy do osiedli starzejących się, a tym samym, że nie oferuje ono atrakcyjnych warunków zamieszkania dla ludzi młodych. Zostają w nim bowiem tylko ci, których nie stać na zmianę swojego miejsca mieszkania. Z badań ankietowych wynika jednak, że mieszkańcy Rogatki to ludzie dobrze wykształceni (31\% zadeklarowało wykształcenie wyższe, a 29\% średnie). Udział osób deklarujących wykształcenie podstawowe lub zawodowe jest stosunkowo

\footnotetext{
${ }^{1}$ Dane uzyskane ze SM Rogatka. Stan z marca 2014 r.
} 
niewielki. Osiedle to zamieszkują przedstawiciele różnych grup zawodowych, przy czym wyraźnie dominują wśród nich różnego rodzaju specjaliści (20\%), w tym nauczyciele, pielęgniarki, tłumacze, technicy i średni personel (14\%) oraz pracownicy usług osobistych (11\%), natomiast brak jest przedsiębiorców i osób na stanowiskach kierowniczych.

Osiedle Rojna powstało niemal w tym samym czasie, co osiedle Rogatka. Wprawdzie pierwsze budynki zostały wzniesione jeszcze w II połowie lat 70., ale ich zasiedlenie nastąpiło dopiero od roku 1980. Obecnie na osiedlu znajduje się 261 domów. Osiedle to, w przeciwieństwie do Rogatki jest osiedlem budownictwa jednorodzinnego szeregowego, które budowano etapami. Niemniej jednak, z uwagi na okres wykonania (lata 70. i 80.) cechuje je również pewna powtarzalność w zakresie formy, wielkości i jakości wykonania. Generalnie na osiedlu występują 3 rodzaje domów: szeregowe, łańcuchowe i atrialne. Ich powierzchnia użytkowa jest podobna i wynosi od 104 do $109 \mathrm{~m}^{2}$. W większości mają one kształt zbliżony do sześcianu i płaski dach, a zostały zbudowane z bloczków gazobetonowych. W ostatnim czasie, z uwagi na powszechny dostęp do różnych materiałów budowlanych mieszkańcy osiedla coraz częściej jednak nadają swoim domom nieco inny charakter, bardziej indywidualny. Wprawdzie najbardziej widoczne zmiany dotyczą głównie elewacji budynków (różne sposoby tynkowania oraz malowania ścian zewnętrznych), okien oraz pokryć dachowych, niemniej jednak podejmowane przez nich działania pozytywnie wpływają na cały wizerunek osiedla. W zdecydowanej większości domy są 3-kondygnacyjne (wyjątek stanowi zabudowa atrialna). Każdy dom ma własną działkę (jej powierzchnia waha się od 230 do $470 \mathrm{~m}^{2}$ ), która daje możliwość codziennego wypoczynku na świeżym powietrzu, a do tego garaż. Działki generalnie są zadbane, często zadrzewione i schludnie ogrodzone. Budynki od samego początku wyposażono także w podstawową infrastrukturę techniczno-sanitarną jak: wodociąg, kanalizacja, gaz ziemny, centralne ogrzewanie oraz elektryczność, co sprawia, że mieszkańcy żyją tam w komfortowych warunkach. Ponadto dużym atutem osiedla znacznie ułatwiającym codzienne przemieszczanie się jest bardzo dobry stan infrastruktury drogowej. Wszystkie znajdujące się, na tym obszarze uliczki są w dobrym stanie technicznym, a przy tym są oświetlone i wyasfaltowane. Od 2013 roku osiedle ma też system ścieżek rowerowych. Badane osiedle jest również dobrze zaopatrzone w różnego rodzaju usługi. Na jego terenie oraz $\mathrm{w}$ jego najbliższym sąsiedztwie znajduje się w sumie 10 punktów handlowych i usługowych, tj. restauracja, klub fitness, solarium, sklep z oknami PCV, a także supermarket Tesco. Ponadto w granicach badanego obszaru funkcjonuje znana i mająca dużą renomę, nie tylko na osiedlu, ale także w całej Łodzi, klinika okulistyczna - Jasne Błonie, oferująca kompleksowe usługi w zakresie leczenia chorób oczu. 
Osiedle Rojna liczy 966 mieszkańców. Co ciekawe, również i tutaj dominują emeryci i renciści (29\%). Zdecydowana większość mieszkańców ma wykształcenie wyższe (zadeklarował je co drugi badany) oraz średnie, na które wskazało 38\% ankietowanych. Najczęściej występujące grupy zawodowe to lekarze, informatycy, przedsiębiorcy, nauczyciele akademiccy i przedstawiciele średniego personelu biurowego.

\subsection{Zróżnicowanie jakości życia mieszkańców w wybranych osiedlach}

Przedstawione powyżej obrazy dwóch jednostek osiedlowych, jakkolwiek podobne pod pewnymi względami dowodzą jednak zróżnicowania warunków życia. Każda z nich ma bowiem walory indywidualne i niepowtarzalne, których brak tej drugiej. Na tle tych „obiektywnych” warunków ciekawe jest pytanie jak sami mieszkańcy postrzegają swoje osiedle i jaki mają do niego stosunek. Wychodząc z założenia, że współcześnie osiedlom blokowym powstałym w okresie PRL-u przypisuje się więcej negatywnych niż pozytywnych cech, należy się spodziewać, że osiedle Rogatka zostanie ocenione znacznie słabiej przez swoich mieszkańców niż osiedle Rojna. A jak jest naprawdę?

Analiza wypowiedzi mieszkańców osiedla Rogatka ujawniła, że mieszkańcy pomimo negatywnych stereotypów swoje osiedle oceniają generalnie w kategoriach pozytywnych, co nie oznacza, że nie dostrzegają jego wad. Świadczy o tym m.in. fakt, że tylko nieznacznie ponad $40 \%$ badanych odczuwa satysfakcję z zamieszkania na tym osiedlu. Blisko $45 \%$ respondentów określiło „Rogatkę” jako miejsce ładne i przyjazne. W ich opinii największymi atutami osiedla są walory ekologiczne (58\% odpowiedzi), duży udział terenów zielonych (49\%), widok z okien na Park Piastowski (45\%) oraz cisza i spokój (66\%). Respondenci pozytywnie ocenili również poziom infrastruktury w zakresie dostępu do usług bytowych. W szczególności powodem ich zadowolenia jest bliskość placówek handlowych (głównie sklepów spożywczych - 48\%) oraz dogodne położenie komunikacyjne (34\%). Ponadto wysoko oceniają oni także infrastrukturę techniczną osiedla, w tym liczbę i jakość chodników (52\%), stan ulic (45\%) oraz jego oświetlenie (31\%). Wyjątek stanowi liczba miejsc parkingowych, która przez zdecydowaną większość mieszkańców została oceniona negatywnie. Aż 70\% respondentów stwierdziło, że ich liczba jest zdecydowanie za mała. W tym kontekście zastanawiający jest fakt, że nikt nie postrzega kwestii rosnącej liczby samochodów w kategoriach konsekwencji ekologicznych na osiedlu. Tymczasem nowe miejsca parkingowe najczęściej pozyskiwane są kosztem osiedlowych trawników. Żaden z respondentów nie zwrócił również uwagi na to, iż zmotoryzowani adaptują chodniki na miejsca postoju niszcząc w ten sposób krawężniki oraz utrudniając ruch pieszym. 
Poza „parkingami” źródłem niezadowolenia mieszkańców są przede wszystkim stosunki społeczne panujące na osiedlu. Prawie co druga osoba (40\%) wymieniła tę cechę jako wadę osiedla, problem, który obniża jakość życia. Należy dodać, że ankietowani artykułując uwagi na temat stosunków społecznych mieli na myśli zarówno stosunki z sąsiadami, jak i charakter społeczny osiedla. W ich opinii jakość życia na osiedlu przede wszystkim uprzykrzają chuligani (często z sąsiednich osiedli). Osiedle Rogatka nie jest strzeżone, ani ogrodzone, a więc łatwo dostępne dla osób z zewnątrz. Do wizyt na osiedlu zachęca również Park Piastowski. Właśnie w nim przede wszystkim, zdaniem ankietowanych zbierają się grupy młodzieży i lokalnych pijaczków, co w dużym stopniu obniża poczucie bezpieczeństwa. Na marginesie warto dodać, że m.in. również z tego powodu mieszkańcy nie czują się tu bezpiecznie. Tylko niecałe 20\% badanych postrzega swoje osiedle jako miejsce bezpieczne do życia. Ponadto, jedynie niewielka część respondentów (8\%) utrzymuje kontakty ze swoim sąsiadami. Zdecydowana większość zapytana o stosunki sąsiedzkie odpowiedziała, że nie utrzymuje z nimi żadnych kontaktów, poza zwyczajowym „dzień dobry”, a jeżeli już to są to kontakty zupełnie przypadkowe. Poza wymienionymi, częstym źródłem niezadowolenia mieszkańców z osiedla Rogatka są warunki zamieszkania, jakie ono oferuje. Tylko 25\% ankietowanych pozytywnie ocenia swoje mieszkanie i jest zadowolona ze standardu samego bloku. Pozostali najczęściej skarżyli się na zbyt cienkie ściany (67\%), zbyt małe pomieszczenia (45\%), brak własnej działki, ogródka (35\%), brudne i zaniedbane klatki schodowe (38\%). W kontekście przedstawionych odpowiedzi nie dziwi fakt, że badani mieszkańcy osiedla Rogatka w zdecydowanej większości nie identyfikują się ze swoim osiedlem ani z jego mieszkańcami. Tylko 24\% mieszkańców zapytana o stosunek do miejsca zamieszkania odpowiedziała „lubię to miejsce”. Pozostali najczęściej utożsamiali się albo tylko ze swoim adresem (36\%), albo wręcz marzyli, aby się z tego miejsca jak najszybciej wyprowadzić (30\%). Dokąd? Najczęściej do własnego domu jednorodzinnego (55\%), z dużym ogrodem, gdzieś na peryferiach, w pobliżu lasu lub parku (28\%). Można przypuszczać, że marzenia te są oznaką pewnego zmęczenia badanych zbyt ciasną przestrzenią życiową, jaką oferują mieszkania w blokach.

W powszechnej opinii osiedle Rojna oferuje znacznie lepsze warunki do życia niż Rogatka. I chyba coś w tym jest, gdyż sami mieszkańcy wyraźniej dostrzegają, a co za tym idzie i podkreślają, jego zalety niż wady, o czym świadczy jednomyślność respondentów w werbalizowaniu satysfakcji z miejsca zamieszkania. $100 \%$ badanych wyraziło opinię, o pełni zadowolenia z faktu zamieszkania na tym osiedlu. W największym stopniu źródłem tego zadowolenia są walory ekologiczne osiedla (49\%). W odczuciu badanych jest to miejsce ciche i spokojne, czemu m.in. sprzyja niewielki 
ruch pojazdów w granicach omawianego obszaru. Ponadto, zdaniem większości, jest ono również ładne, przyjazne i zadbane. Wysoko waloryzowano także zieleń osiedla, którą w dużej mierze kreują sami mieszkańcy poprzez urządzanie swoich działek. Badani docenili fakt posiadania własnego ogrodu, który daje im więcej wolnej, prywatnej przestrzeni. Wszystkie te elementy odzwierciedla wysoka ocena osiedla pod względem warunków codziennego wypoczynku (86\% badanych uznało je za dobre). Ponadto, podobnie jak w przypadku mieszkańców Rogatki respondenci $\mathrm{z}$ osiedla Rojna doceniają jego infrastrukturę. Przede wszystkim pozytywnie oceniali dostępność komunikacyjną osiedla (48\%), w tym głównie możliwość szybkiego dojazdu samochodem do centrum i dostępność do placówek handlowych (52\%). Warto dodać, że badanych satysfakcjonuje zarówno ich liczba oraz jakość asortymentu czy obsługi. Nieporównywalnie lepiej niż mieszkańcy Rogatki, ankietowani z osiedla Rojna oceniają natomiast standard życia na swoim osiedlu. Ma to związek przede wszystkim z posiadaniem przez nich własnego domu dobrze wyposażonego w niezbędne elementy infrastruktury komunalnej i ogródek. Ponadto w znacznie lepszym świetle postrzegają także stosunki z sąsiadami i charakter społeczny osiedla. Dość powszechne wśród tych mieszkańców jest bowiem utrzymywanie kontaktów z sąsiadami (75\%), najczęściej z tej samej ulicy. Warto dodać, że kontakty te często przybierają różne formy i nie ograniczają się tylko do grzecznościowego dzień dobry. Powszechna wśród tych mieszkańców jest bowiem wzajemna pomoc sąsiedzka rozumiana jako „pożyczki drobiazgów”, pomoc przy remoncie domu czy też wzajemna opieka nad dziećmi w domu czy na placu zabaw. Ponadto część respondentów $(12 \%)$ wskazała na towarzyski charakter tych relacji. Mieszkańcy osiedla Rojna nie narzekają również na chuliganów, dzięki czemu swoje osiedle postrzegają jako bezpieczne (78\%). Co ciekawe, dla wielu z nich poczucie bezpieczeństwa wynika także z życia pośród ludzi, których się zna i którym się ufa oraz z życzliwości sąsiadów. Odpowiednikiem chuligana na tym osiedlu są $\mathrm{w}$ opinii mieszkańców jedynie działkowicze z pobliskich ogródków działkowych, którzy urządzają zbyt głośne imprezy. Obok wielu pozytywnych stron zamieszkania na tym osiedlu, ma ono jednak również i swoje wady. Zdaniem mieszkańców kryją się one przede wszystkim w zbyt ścisłej zabudowie osiedla (19\%), która ogranicza (jak to wyrazili) ich prywatność. Często, jak podkreślali, szczególnie przebywając w ogrodzie czują się jak „pod lupą”, towarzyszy im bowiem świadomość, że mogą być obserwowani przez mieszkańców sąsiednich domów. Ponadto niektórzy (18\%) narzekali na hałas generowany albo przez ruch uliczny na ulicy Szczecińskiej bądź Rojnej lub położony w sąsiedztwie kościół pw. Miłosierdzia Bożego. Dla co dziesiątego, źródłem niezadowolenia był rodzaj materiałów konstrukcyjnych budynków, gdyż nie wycisza dostatecznie hałasów zza ściany. Pojedyncze 
osoby (3\%) narzekały także na zbyt małą działkę i niedostateczną powierzchnię wolnej przestrzeni na osiedlu. W świetle wielu wymienionych przez mieszkańców pozytywnych stron zamieszkania na osiedlu, nie dziwi jednak fakt, że w przeciwieństwie do mieszkańców Rogatki mocno identyfikują się oni ze swoim osiedlem i mieszkającymi tam ludźmi. Ponad 95\% badanych określiło, że lubi to miejsce i nie wyobraża sobie zamieszkania w innym. Stanowisko to potwierdziło również pytanie o wymarzone miejsce zamieszkania. Rzadko bowiem zdarzało się, aby ankietowani wskazali konkretne miejsce w przestrzeni, miasto czy kraj, a jeżeli już, to najczęściej przybierało ono kształt osiedla Rojna z lekkimi modyfikacjami (np. odnośnie do mniejszego hałasu).

\subsection{Podsumowanie}

Wybrane do badań osiedla Rojna i Rogatka, mimo położenia w granicach tej samej jednostki osiedlowej Teofilów w Łodzi cechuje zróżnicowanie, przede wszystkim w sferze jakości życia, w mniejszym stopniu jego warunków. Osiedla, choć różnią się pod względem fizjonomii i formy zabudowy, oferują w miarę zbliżone warunki życia, z uwagi na podobny okres powstania i lokalizację w przestrzeni. Dysproporcje w tym względzie nie są zatem tak wyraźne jak w centrum miasta, gdzie obok starej i zdegradowanej zabudowy z początku XX w. można spotkać nowoczesne i reprezentacyjne biurowce lub apartamentowce. W odniesieniu do jakości życia, różnica między badanymi osiedlami jest już znacznie wyraźniejsza i w dużej mierze wynika ona z relacji, jakie zachodzą między człowiekiem a formami zabudowy. Zdecydowanie lepiej bowiem postrzegają i oceniają swoje osiedle respondenci mieszkający na co dzień w domu z własnym ogródkiem i garażem niż ci z zabudowy blokowej.

Ukształtowanie i sposób zagospodarowania osiedla, w tym również i jego architektura, silnie oddziałują na człowieka, kreując jego jakość życia. Jak trafnie zauważył Wallis „miasto stwarza i udostępnia przestrzenno-materialne formy zarówno dla kontaktów, jak i dla barier między ludźmi. Tym samym z jednej strony podtrzymuje jedne więzi, ale równocześnie utrudnia, a często nawet uniemożliwia rozwój innych, które dana zbiorowość zdolna byłaby w sobie rozwinąć" (Wallis 1971). Z punktu widzenia praktyki gospodarczej osiedlem jest każdy zespół wydzielonych administracyjnie budowli mieszkaniowych. Osiedle w ujęciu społecznym musi natomiast dodatkowo sprzyjać jeszcze rozwojowi jego mieszkańców. Za najbardziej przyjazne i sprzyjające rozwojowi uchodzą te osiedla, które umożliwiają jednostce zaspokojenia jej potrzeb i dążeń, które można dowolnie kształtować zgodnie ze swoimi wymaganiami. Ponadto dobrze jest, jeżeli osiedle, obok potrzeb estetycznych, zaspokaja również potrzeby 
intymności, bliskości i wspólnoty. Innymi słowy sprzyja harmonijnemu współżyciu jego mieszkańców, umożliwia rozwój osobistych niesformalizowanych kontaktów i więzi, rozwój życia kulturalnego, poczucie wspólnoty i łatwość współdziałania w potrzebie. W związku z tym osiedle domów jednorodzinnych, nawet tych w zabudowie szeregowej, oceniane jest lepiej niż tzw. blokowisko, „choćby dlatego, że parterowe czy piętrowe domki w zdecydowanie większym stopniu pozwalają na żywiołowe i osobiste kształtowanie każdej fasady przez swych użytkowników, podczas gdy wielkie, wielopiętrowe budynki mieszkalne pozbawiają mieszkańców możliwości indywidualnego kształtowania swojej ulicy" (Wallis 1971). Tereny między blokami nie są miejscem atrakcyjnym dla kameralnych i intymnych spotkań. „Uczucie jakie przed nimi ogarnia, bliższe jest raczej wrażeniu, że ma się do czynienia z bezosobowymi koszarami, niż odczuciu swojskości i wspólnoty" (Wallis 1971). W związku z tym, mieszkańcy osiedla Rojna swoje marzenia o idealnym miejscu zamieszkania identyfikują tylko ze swoim osiedlem podczas gdy ci „drudzy” swoją przyszłość najchętniej widzieliby w innym miejscu, gdzieś w domu jednorodzinnym z własnym ogrodem, z dala od sąsiadów.

\section{LITERATURA}

Borowicz, Grochowski, 1977, Łódzkie osiedla spółdzielcze. Problem wielkości i lokalizacji, [w:] Łódzka spółdzielczość mieszkaniowa, Acta Universitatis Lodziensis, Zeszyty Naukowe UŁ, Nauki Ekonomiczne, Seria III, z 26.

Gorzelak G., 1985, Przestrzenne aspekty jakości życia i sprawiedliwości społecznej, Gospodarka Przestrzenna Polski, t.2, Warszawa.

Hodoly A., 1975, Spożycie i formy jego realizacji w rozwoju gospodarki społeczeństwa socjalistycznego, Biblioteka IHW, nr 118, Warszawa.

Liszewski S., 1995, Zróżnicowanie przestrzenne poziomu i jakości warunków życia ludności w aglomeracjach miejskich (Program badań, pierwsze wyniki), „Acta Universitatis Lodziensis", Folia Geographica, 20.

Liszewski S., 2004, Rola i zadania geografii w badaniach zróżnicowania przestrzennego warunków życia mieszkańców miast. Założenia teoretyczne i programy badań, [w:] I. Jażdżeska (red.), Zróżnicowanie warunków życia ludności w mieście, XVII Konwersatorium Wiedzy o Mieście, Wyd. UŁ, Łódź

Parysek J., 2004, Warunki życia w miastach polskich w okresie transformacji, [w:] I. Jażdzewska, XVII Konwersatorium Wiedzy o Mieście, (red.), Wyd. UŁ, Łódź

Rembowska K., 1994, Przestrzenne zróżnicowanie warunków życia wiejskiej ludności województwa piotrkowskiego na przykładzie wybranych gmin, „Acta Universitatis Lodziensis", Folia Geographica, 18. 
Tobiasz-Lis P., Wójcik M., 2013, Interpreting Contrasts of the Post-Industrial City: The Example of Lodz, "International Journal of Humanities and Social Science", 3 (14), CPI, USA, s. 22-31.

Tobiasz-Lis P., Wójcik M., 2013, Evaluating and interpreting the city using a photo projective method. The example of Łódź, "Geographia Polonica”, 86 (2), IG\&SO PAS, s. 137-152.

Wallis A., 1971, Socjologia i kształtowanie przestrzeni, Państwowy Instytut Wydawniczy, Warszawa. 